\title{
Enzymatic Hydrolysis of Porang by Streptomyces violascens BF 3.10 Mannanase for the Production of Mannooligosaccharides
}

\author{
A. H. Safitri ${ }^{a}$, Yopi $^{b}$, \& A. Meryandini ${ }^{\mathrm{c}, \mathrm{d}, *}$ \\ ${ }^{a}$ Major Program of Biotechnology, Graduate School, Bogor Agricultural University \\ ${ }^{b}$ Biocatalyst and Fermentation Laboratory, Research Center for Biotechnology, Indonesian Institute of Sciences \\ Jln. Raya Bogor Km. 46 Cibinong 16911, Indonesia \\ 'Department of Biology, Faculty of Mathematic and Natural Sciences \\ ${ }^{\mathrm{d}}$ Research Centre for Bioresources and Biotechnology, Bogor Agricultural University \\ Kampus IPB Darmaga, Bogor 16680, Indonesia \\ (Received 13-06-2014; Reviewed 07-07-2014; Accepted 12-09-2014)
}

\begin{abstract}
Porang (Amorphophallus muelleri Blume) is an indigenous Indonesian plant containing high hemicellulose as a source of glucomannan. An alternative way to produce a good quality of mannooligosaccharides was through hydrolysis of glucomannan by endo- $\beta$ mannnase from actynomicetes. Based on 16S rRNA analysis, BF 3.10 isolate, isolated from Bukit Duabelas National Park soil, Jambi was identified as Streptomyces violascens BF 3.10. Reducing sugar was analyzed by dinitrosalicylic acid methods. The highest reducing sugar was achieved at the 72 hours of incubation. Mannanase of isolate BF 3.10 had the highest activity at $\mathrm{pH} 6$ and temperature of $70^{\circ} \mathrm{C}$ with enzyme activity of $16.38 \mathrm{U} / \mathrm{mL}$ and was stable at $4{ }^{\circ} \mathrm{C}$ for $48 \mathrm{~h}$. During 5-hour of hydrolysis with substrate concentration of $0.25 \%, 0.5 \%$, and $1 \%$ porang glucomannan dissolved in $10 \mathrm{~mL}$ enzyme, mannooligosaccharides were produced with the degree of polymerization of 2-3. Visualization of the products by using thin layer chromatography (TLC) and high performance liquid chromatography (HPLC) methods showed that mannooligosaccharides produced comprised of glucose, mannobiose, mannotriose, and mannotetraose. The degree of polymerization and the simple sugars produced indicated that mannanase produced by $S$. violascens actively catalyzed the hydrolysis of 1.4- $\beta$-D-mannoside linkage from $\beta$-1.4mannan backbone, that eventually produced simple sugars of mannooligosaccharides.
\end{abstract}

Key words: glucomannan, mannanase, mannooligosaccharides, porang, Streptomyces violascens

\begin{abstract}
ABSTRAK
Porang (Amorphophallus muelleri Blume) merupakan tanaman asli Indonesia yang mengandung kadar hemiselulosa dalam bentuk glukomanan yang tinggi. Salah satu alternatif untuk memperoleh manooligosakarida dengan kualitas baik adalah melalui hidrolisis glukomanan oleh enzim endo $\beta$ mananase dari aktinomisetes. Berdasarkan analisis 16S rRNA isolat BF 3.10 yang diisolasi dari tanah Taman Nasional Bukit Duabelas, Jambi teridentifikasi sebagai Streptomyces violascens BF 3.10. Kadar gula pereduksi ditentukan menggunakan metode asam dinitrosalisilat (DNS). Kadar gula pereduksi tertinggi dihasilkan pada jam ke-72 inkubasi. Mananase S. violascens mempunyai aktivitas tertinggi pada $\mathrm{pH} 6$ dan suhu $70^{\circ} \mathrm{C}$ dengan aktivitas enzim sebesar $16.38 \mathrm{U} / \mathrm{mL}$ dan stabil pada suhu $4{ }^{\circ} \mathrm{C}$ selama $48 \mathrm{jam}$. Selama 5 jam waktu hidrolisis, reaksi dengan konsentrasi substrat $0,25 \%, 0,5 \%$, dan $1 \%$ glukomanan porang yang dilarutkan dalam $10 \mathrm{~mL}$ enzim menghasilkan manooligosakarida dengan derajat polimerisasi 2-3. Visualisasi produk hidrolisis mengggunakan metode thin layer chromatography (TLC) dan high performance liquid chromatography (HPLC) menunjukkan bahwa jenis manooligosakarida yang dihasilkan adalah glukosa, manobiosa, manotriosa, dan manotetrosa. Derajat polimerisasi dan gula-gula sederhana yang terbentuk menunjukkan bahwa mananase $S$. violascens bekerja secara aktif mengatalisis reaksi hidrolisis ikatan 1,4- $\beta$-D-manosida dari rantai utama $\beta-1,4-m a n n a n$ sehingga menghasilkan gula-gula sederhana manooligosakarida.
\end{abstract}

Kata kunci: glukomannan, mananase, manooligosakarida, umbi Porang, Streptomyces violascens

*Corresponding author:

E-mail: ameryandini@yahoo.com 


\section{INTRODUCTION}

Porang (Amorphophallus muelleri Blume) is one of 27 Amorphophallus spp in Indonesia out of a total of 170 types known in the world (Poerba et al., 2008). This corm is considered wild-type plant and has not been widely used despite its abundant availability in Indonesia (Sumarwoto, 2004). Currently, porang is commonly exported in the form of porang flour with a low quality and a relatively low price. However, the difficulty in processing due to its high oxalic acid content caused porang to be considered as a material with limited function as food and feed.

Porang is found to be the source of alternative carbohydrate with the highest amount of glucomannan out of all Amorphophallus in Indonesia (Sumarwoto, 2004). High amount of glucomannan is found in the corm part of porang plant. The structure of glucomannan composed of $\beta$-(1.4) linked D-mannose and D-glucose residues in certain molar ratio (Albrecht et al., 2009). The ratio of mannose to glucose in glucomannans depends on the origin of glucomannan (Al-ghazzewi et al., 2007; Chua et al., 2010) and ranges from around 1.5:1 to 4.2:1 (Tester \& Al-ghazzewi, 2013). Glucomannan content of porang ranges from 35\%-55\% (Sumarwoto, 2004). High mannan content in porang becomes economically potential to be explored further.

Glucomannan with its main component as D-mannose, is important for several industries, including food, feed, and feed stocks (Dhawan \& Kaur, 2007). Glucomannan can be broken down by enzymes mannanase into simple sugars. Mannooligosaccharides can be produced by hydrolysis of mannan by a synergistic action of endo-mannanases and exo-acting $\beta$-mannosidase. Mannooligosaccharides are non-digestible oligosaccharides and could be potentially applied as dietary fiber and prebiotics (Yopi et al., 2006).

According to Roberfroid (2007), prebiotics are defined as selectively fermented ingredients allowing specific changes, both in the composition and/or activity in the gastrointestinal microflora, that give benefits upon the well-being and health of the host. Feed supplemented with mannooligosaccharides (MOS) will significantly affect the intestinal microflora of chicken by increasing the Bifidobacterium spp. and Lactobacillus spp., and decreasing the Enterobactericeae groups (Fernandez et al., 2002). MOS also positively affected on the fecal microbial population by reduction of E. coli and Salmonella number (Khanongnuch et al., 2006). The effect of MOS supplementation in the diet of broilers shows a significantly higher body weight gain and improvement in feed efficiency as compared to the control diet (Shendare et al., 2008). Moreover, mannooligosaccharides are potential to be used as non-nutritional and functional food additives for selective growth of intestinal beneficial microflora, reduction of dietary fat absorption, and inhibition of the increased blood pressure (Jian et al., 2013).

The aim of this study was to produce mannooligosaccharides through enzymatic hydrolysis of porang glucomannan and to analyze mannooligosaccharides product by thin layer chromatography and high perfor- mance liquid chromatography. This study also determined the optimum production time and characterized the optimum conditions of mannanase that can be used to produce prebiotic mannooligosaccharides from porang.

\section{MATERIALS AND METHODS}

\section{Physico-chemical Analysis of Porang Flour}

Porang flour was purchased from PT Ambico Surabaya, East Java, Indonesia. The particle size of porang flour obtained was 80 meshs. Porang flour was weighed and subsequently processed for physico-chemical properties analysis i.e., moisture, protein, lipid, crude fiber, and ash contents of the isolated samples (AOAC, 1995).

\section{Rejuvenation of Isolate and Preparation of Inoculum}

Actinomycetes BF 3.10 isolate from Bukit Duabelas National Park soil, Jambi has been known to possess mannanolitic activity. The isolate was rejuvenated in solid media containing of $0.5 \%$ glucomannan and incubated at $30^{\circ} \mathrm{C}$ for $4 \mathrm{~d}$.

\section{Mannanase Production and Mannanase Assay}

The medium for mannanase production consisted of $0.5 \%$ porang glucomannan, $0.05 \%$ yeast extract, $0.075 \%$ peptone, $0.14 \% \quad(\mathrm{NH} 4)_{2} \mathrm{SO}_{4^{\prime}} \quad 0.2 \% \quad \mathrm{KH}_{2} \mathrm{PO}_{4^{\prime}}$ $0.03 \% \mathrm{MgSO}_{4} 7 \mathrm{H}_{2} \mathrm{O}, \quad 0.03 \% \mathrm{CO}\left(\mathrm{NH}_{4}\right)_{2}, 0.03 \% \mathrm{CaCl}_{2}$, $0.0005 \% \quad \mathrm{FeSO}_{4} 7 \mathrm{H}_{2} \mathrm{O}, \quad 0.00016 \% \quad \mathrm{MnCl}_{2} 7 \mathrm{H}_{2} \mathrm{O}, 0.00014 \%$ $\mathrm{ZnSO}_{4} 7 \mathrm{H}_{2} \mathrm{O}$, and $0.0002 \% \mathrm{CoCl}_{2}$ (Mendels \& Sternberg, 1976). The media were sterilized at $121^{\circ} \mathrm{C}$ for $15 \mathrm{~min}$. Mannanase production by isolate BF 3.10 was induced by cultivating 1 corckborer microorganism (diameter \pm 1 $\mathrm{cm}, 4$ days old) in $100 \mathrm{~mL}$ of production liquid media in a $500 \mathrm{~mL}$ Erlenmeyer. The culture was incubated in a shaking incubator (Taitec) with $200 \mathrm{rpm}$ agitation at 30 ${ }^{\circ} \mathrm{C}$ for $5 \mathrm{~d}$. The crude mannanase enzyme preparation was obtained in the form of culture supernatant by centrifugation at $12000 \mathrm{rpm}$ for $10 \mathrm{~min}$ at $4^{\circ} \mathrm{C}$ temperature.

Mannanase activity was evaluated by measuring the amount of reducing sugars produced by the 3.5-dinitrosalicylic acid (DNS) method (Miller, 1959) by using mannose as a standard. The mannanase activity was assayed by incubating the enzyme solution into substrate of $0.5 \%$ locust bean gum (Merck, Darmstadt, Germany) prepared in $50 \mathrm{mM}$ phosphate buffer with $\mathrm{pH} 6$ for 30 min. The reaction was stopped by immersing the test tube in boiling water for $20 \mathrm{~min}$. The yielded reducingsugar substance was assessed by spectrophotometer with a wavelength of $540 \mathrm{~nm}$ (Hitachi, U-3900H, Tokyo, Japan). One unit of mannanase activity was defined as the amount of enzyme which produces $1 \mu \mathrm{mol}$ mannose per minute under the assay condition.

The curve of bacterial growth was drawn based on cell's biomass dry weight. The culture of bacteria was inoculated into $30 \mathrm{~mL}$ mineral media of $0.5 \%$ porang glucomannan, shaken at $200 \mathrm{rpm}$ and $30{ }^{\circ} \mathrm{C}$ for $5 \mathrm{~d}$. Sample 
was harvested every day, and then centrifuged at 12000 rpm with $4{ }^{\circ} \mathrm{C}$ temperature for $20 \mathrm{~min}$. The pellet was sieved and dried in an oven at $50{ }^{\circ} \mathrm{C}$. The biomass was weighed and plotted to incubation time to obtain bacterial growth curve.

\section{Mannanase Characterization}

Enzyme characterizations conducted in this experiment were determination of optimum $\mathrm{pH}$ and temperature as well as the stability of crude extract of mannanase enzyme. Optimum $\mathrm{pH}$ was determined by analyzing the activity of crude extract enzyme at range of $\mathrm{pH} 3-10$ with 1 interval by using the following buffer systems (50 $\mathrm{mM})$ : sodium citrate $(\mathrm{pH} 3-5)$, sodium phosphate $(\mathrm{pH}$ 5.5-7.5), Tris $\mathrm{HCl}$ ( $\mathrm{pH}$ 7.5-9), and glycine-NaOH (pH 910). Optimum temperature was determined by reacting the enzyme and substrate at various temperatures, ranging from $30-100{ }^{\circ} \mathrm{C}$ with a $10{ }^{\circ} \mathrm{C}$ interval, at the optimum $\mathrm{pH}$ obtained before. The stability of crude extract of mannanase enzyme was analyzed by incubating the enzyme (without substrate) at three different temperatures $\left(30{ }^{\circ} \mathrm{C}, 4^{\circ} \mathrm{C}\right.$, and optimum temperature). Crude enzyme extract was analyzed every hour (from $1^{\text {st }}$ to $5^{\text {th }}$ hour) and every $24 \mathrm{~h}$ at its optimum $\mathrm{pH}$ and temperature with $0.5 \%$ mannan substrate.

\section{Enzymatic Hydrolysis}

Enzymatic hydrolysis was carried out at various substrate concentrations $(\mathrm{w} / \mathrm{v})$ i.e., $0.25 \%, 0.50 \%, 1 \%$ in enzyme solution and various reaction times i.e., 3 , 5 , and $24 \mathrm{~h}$. The reactions were carried out in $50 \mathrm{~mL}$ Erlenmeyer flasks containing $10 \mathrm{~mL}$ of reaction mixtures in rotary shaker (Stuart orbital incubator S1500, Staffordshire, United Kingdom) at $30{ }^{\circ} \mathrm{C}$. The samples were taken at regular intervals (after 3, 5, and $24 \mathrm{~h}$ ) and the reactions were stopped in boiling water for $15 \mathrm{~min}$. The samples were then centrifuged at $12000 \mathrm{rpm}$ for 15 min and the supernatant, as the product of hydrolysis, was analyzed both quantitatively and qualitatively.

\section{Analysis of Mannooligosaccharides}

The product of hydrolysis was analyzed by calculating the reducing sugar, total sugar content, and the degree of polymerization. Thin layer chromatography (TLC) and high performance liquid chromatography (HPLC) were used for analysis of mannooligosaccharides. Analysis of total sugar was performed by applying phenol-sulphuric acid method with modifications described by Dubois et al. (1956). Reducing sugar was analyzed by DNS method (Miller, 1959). The degree of polymerization was calculated from the ratio of total sugars and reducing sugars yielded.

The types of simple sugars were analyzed by thin layer chromatography (TLC) method on silica gel $60 \mathrm{~F}_{254}$ plates (Merck Art20-20 cm, Darmstadt, Germany) by using a solvent of n-butanol:acetic acid:aquades (12:6:6, by volume). The product of hydrolysis was applied on silica plate comprising of $4 \mu \mathrm{L}$ sample and $2 \mu \mathrm{L}$ standard solution. Acting as standards were glucose and mannooligosaccharides (mannose, mannobiose, mannotriose, mannotetraose, mannopentose, and mannohexose). The spots formed were visualized by heating at $121{ }^{\circ} \mathrm{C}$ for \pm 15 min after spraying the plate with staining solution consisted of $\alpha$-diphenylamine $0.2 \mathrm{~g}, 10$ $\mathrm{mL}$ of acetone, $1.5 \mathrm{~mL}$ of phosphate acid, and $0.2 \mathrm{~mL}$ of aniline. Mannooligosaccharides products were analyzed by HPLC under the following conditions: column $250 \mathrm{x}$ $4.6 \mathrm{~mm}$ i.d. Zorbax SIL coated with 3-amino propyl silane, mobile phase was acetonitrile and distillated water in ratio of $75: 25(\mathrm{v} / \mathrm{v})$, column temperature $\left(30^{\circ} \mathrm{C}\right)$, flow rate $(1.4 \mathrm{~mL} / \mathrm{min})$ and detector Agilent Technologies 1200 series refractive index monitor (RID).

\section{RESULTS AND DISCUSSION}

\section{Chemical Composition of Porang Flour}

Chemical composition obtained from proximate and Van Soest analysis of porang flour is shown on Table 1. Proximate and Van Soest analysis showed that porang contained high hemicellulose $(75.72 \%$ polysaccharides), presumably most of them was glucomannan. This composition resembled the glucomannan content in konjac flour, ranged from $70 \%-90 \%$ (Thomas, 1997). On the other hand, cellulose was found in very little amount in porang.

\section{Determination of Optimum Production Time and Activity of Mannanase}

Porang flour contained approximately 75\% mannan polysaccharides that could be used as the carbon source for bacterial growth. The highest activity of mannanase was achieved by $S$. violascens BF 3.10 on its optimum growth i.e., at the $72 \mathrm{~h}$ incubation reached $0.76 \mathrm{U} / \mathrm{mL}$ at substrate concentration of $0.5 \%$ glucomannan porang, $200 \mathrm{rpm}$, and $30{ }^{\circ} \mathrm{C}$ (Figure 1). After $72 \mathrm{~h}$ incubation, the cell number decreased, followed by an insignificant decrease in enzyme activity.

Table 1. Chemical composition of porang flour

\begin{tabular}{llr}
\hline Analysis & Constituent & $\%$ \\
\hline Proximate $^{\mathrm{a}}$ & Moisture & 12.28 \\
& Ash & 3.61 \\
& Lipid & 0.36 \\
& Crude protein & 1.61 \\
& Crude fiber & 0.34 \\
& Nitrogen free extract & 81.80 \\
Van Soest $^{\mathrm{b}}$ & Dry weight & 86.47 \\
& NDF & 78.72 \\
& ADF & 3.00 \\
& Hemicellulose & 75.72 \\
& Cellulose & 2.90 \\
& Lignin & 0.08 \\
\hline
\end{tabular}

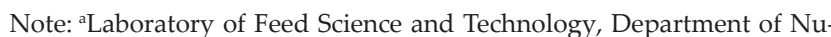
trition and Technology, Faculty of Animal Science, Bogor Agricultural University; ${ }^{b}$ Research Centre for Bioresources and Biotechnology, Institute of Research and Community Empowerment, Bogor Agricultural University. 


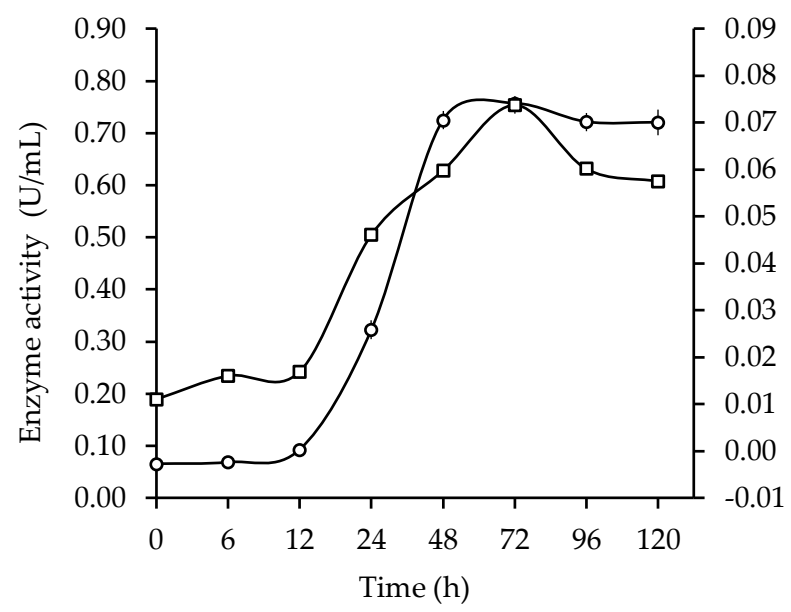

Figure 1. Time course of mannanase production by Streptomyces violascens $\mathrm{BF} 3.10$ in $0.5 \%$ porang glucomannan at 30 ${ }^{\circ} \mathrm{C}, \mathrm{pH}$ 6, $200 \mathrm{rpm}$ : mannanase activity; (-o-), cell biomassa ; (-ロ-).

Bacterial growth was affected by aeration and the amount of nutrition. Low oxygen solubility and slow oxygen replacement through diffusion process were two inhibiting factors for aerobic bacteria to live (Madigan et al., 2006). Porang is highly viscous substrate in water. During the first $24 \mathrm{~h}$, the bacterial growth and activity were low because of the low oxygen availability. But, they started to increase significantly after $24 \mathrm{~h}$ when the viscosity of $0.5 \%$ of porang substrate got lower than that of the previous hour. Agitation could accelerate oxygen replacement in the medium (Meryandini et al., 2008). An agitation speed of $200 \mathrm{rpm}$ in $0.5 \%$ porang substrate in this current study may be able to provide a good condition for bacterial growth to produce enzyme with a high activity. Bhoria et al. (2009) reported that Streptomyces sp. PG-08-03 produced mannanase with activity of $15 \mathrm{U} / \mathrm{mL}$ in $0.5 \%$ guar gum at $72 \mathrm{~h}, 37^{\circ} \mathrm{C}$, and $200 \mathrm{rpm}$ agitation. The optimum time in producing mannanase was then used as a standard harvesting time for the next mannanase production.

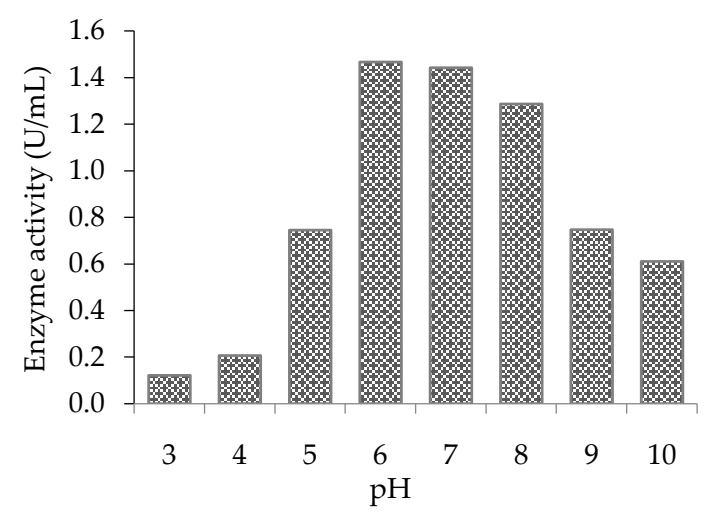

Figure 2. The effect of $\mathrm{pH}$ on mannanase Streptomyces violascens BF 3.10 activity measured at $30^{\circ} \mathrm{C}$ using $50 \mathrm{mM}$ of different buffers

\section{Mannanase Characterization}

Changes in $\mathrm{pH}$ gave various effects on mannanase activity produced by $S$. violascens $\mathrm{BF} 3.10$. At the range of $\mathrm{pH} 3-10$, the activity of mannanase produced by $S$. violascens BF 3.10 showed the highest activity at $\mathrm{pH} 6$ (Figure 2). Low $\mathrm{pH}$ or more alkaline condition led to a significant decrease in enzyme activity. In acidic condition $(\mathrm{pH}<5)$, the activity of enzyme decreased to less than $80 \%$ of its maximum one. Enzyme is a polyionic polymer and thus is highly affected by the changes in $\mathrm{pH}$. Changes in $\mathrm{pH}$ can alter the spread of charges in the active site of all parts of protein molecule's surface (Illanes, 2008). At optimum $\mathrm{pH}$, the structure and active site of an enzyme are in the most suitable condition to bind substrate, resulting in a maximum activity. Microorganism has high diversity in the sensitivity to $\mathrm{pH}$ changes, i.e., Streptomyces galbus NR has an optimum pH of 6.5 (Kansoh \& Nagieb, 2004), whereas for bacterias, Bacillussubtilis WY34 the optimum pH was 6 (Jiang, 2006). For fungal, Aspergillus niger and Trichoderma $s p p$, the highest activity was found at $\mathrm{pH}$ of 5 (Adesina et al., 2013).

Enzyme is highly sensitive to temperature changes. This study showed that mannanase $S$. violascens BF 3.10 as a thermostable enzyme has an optimum temperature at $70{ }^{\circ} \mathrm{C}$ at $\mathrm{pH} 6$ with a maximum activity up to $16.38 \mathrm{U} /$ $\mathrm{mL}$ (Figure 3). Similar to $\beta$-mannanase thermophilic actinomycetes $A$. aculeatus have optimum temperature at 70 ${ }^{\circ} \mathrm{C}$ (Pham et al., 2010), whereas for bacteria, mannanase of Bacillus agaradhaerens strain HMTS15 had an optimum temperature at $75{ }^{\circ} \mathrm{C} \mathrm{pH}$ of 10 (Liao et al., 2011). The enzyme activity decreases slowly as the temperature increases. Enzyme inactivation by temperature occurs because the intermolecular strength weaken, affecting the enzyme's three dimensional stability and reducing its catalytic ability (Bommarius \& Broering, 2005).

Different temperatures affected differently on mannanase stability as shown when it was incubated at 4, 30, and $70{ }^{\circ} \mathrm{C}$ (Figure 4). At its optimum temperature, mannanase activity decreased significantly at the first hour of incubation and at the $5 \mathrm{~h}$ incubation, the activity was lost by $98 \%$. On the other hand, it appeared that the en-

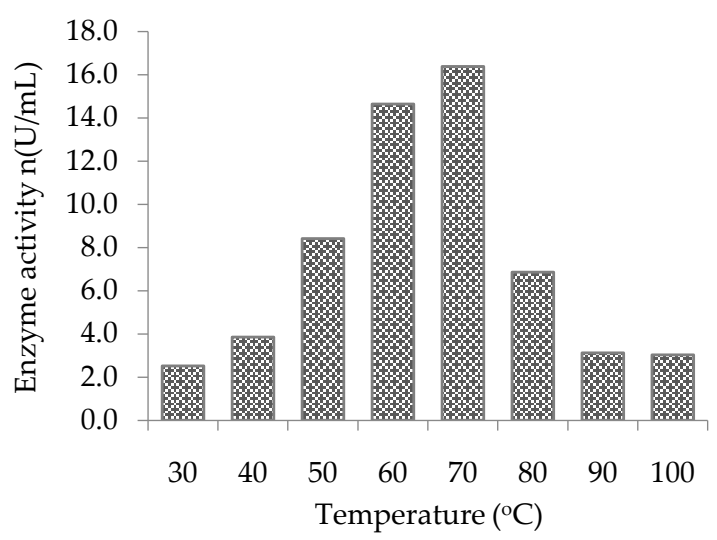

Figure 3. The effect of temperature on the activity of mannanase Streptomyces violascens BF 3.10 measured at $\mathrm{pH} 6$ 


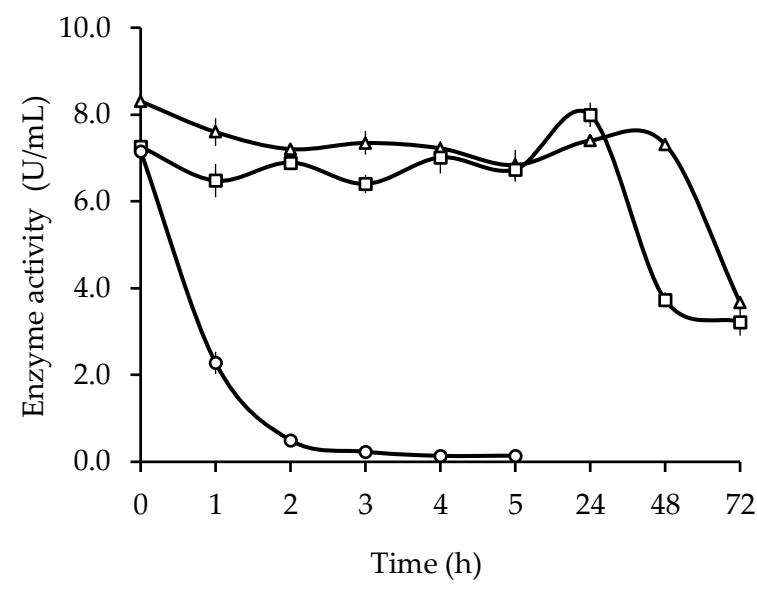

Figure 4. Mannanase stability of Streptomyces violascens BF 3.10 at different storage temperatures measured at $\mathrm{pH} 6$. Enzyme stability was measured at three storage temperatures : $4{ }^{\circ} \mathrm{C}(-\Delta-), 30^{\circ} \mathrm{C}(-\square-)$, and $70^{\circ} \mathrm{C}(-\mathrm{o}-)$.

zyme had longer half-life time at incubation temperature of 4 and $30^{\circ} \mathrm{C}$. Incubation at 4 and $30{ }^{\circ} \mathrm{C}$ could retain the enzyme activity for 48 and 24 hour of incubation, respectively, then the activity significantly decreased by $50 \%$. Temperature has a high impact on enzyme activity and its stability. As the temperature increases, not only chemical reaction rate will increase but also the inactivation rate (Illanes, 2008). This explains why mannanase has a relatively shorter half-life at $70{ }^{\circ} \mathrm{C}$. Mannanase of Penicillium occitanis was reported to lose $50 \%$ of its activity after 4-hour incubation at $60{ }^{\circ} \mathrm{C}$. The immobilized $\beta$-mannanase of Penicillium occitanis retained $40 \%$ of its activity after $30 \mathrm{~min}$ of incubation at $70{ }^{\circ} \mathrm{C}$ (Blibech et al., 2011).

\section{Hydrolysis of Porang Flour by Mannanase S. violascensi BF 3.10}

Porang flour is an economic raw material for MOS production. Enzyme ability and substrate concentration are important factors for polymer hydrolysis process (Jian et al., 2013). In this study, the maximum concentration of porang was set at $1 \%$ due to its high viscosity. High viscosity will reduce enzyme ability to hydrolyze component linkage within substrate (Jian et al., 2013). Hydrolysis time was determined based on mannanase stability, for 3,5 , and $24 \mathrm{~h}$ at $30{ }^{\circ} \mathrm{C}$. For $\leq$ $24 \mathrm{~h}$, mannanase could retain up to $\geq 90 \%$ of its activity. The amount of reducing sugar produced was monitored to determine the ability of mannanase in hydrolyzing porang. At the same reaction time, the higher substrate concentration the more reducing sugar was produced (Figure 5). The highest reducing sugar produced was observed at substrate concentration of $1 \%$. They were $4.375,5.008$, and $5.708 \mathrm{mg} / \mathrm{mL}$ at the incubation for 3,5 , and $24 \mathrm{~h}$, respectively.

Hydrolysis of glucomannan at various substrate concentrations and reaction times resulted in nearly the same degree of polymerization (DP) i.e., 2-3 (Table 2 ). The same DP value from the three different substrate concentrations indicated that the ability of mannanase

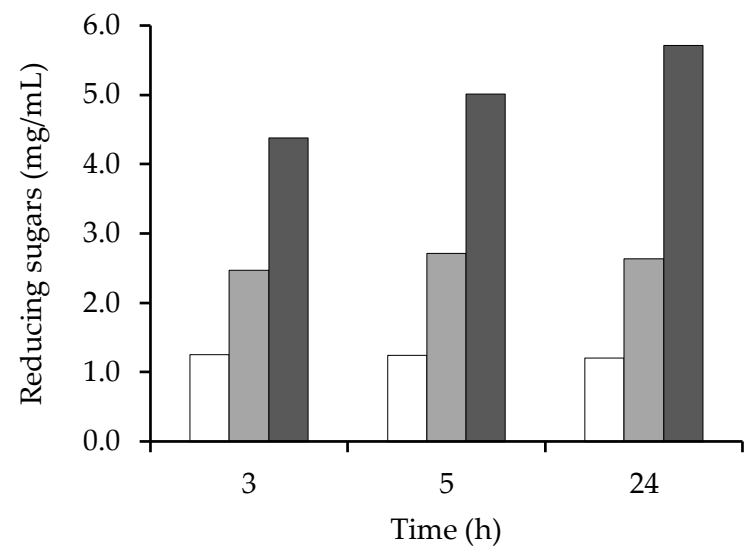

Figure 5. Analysis of reducing sugars as product of hydrolysis, hydrolyzed by mannanase enzyme of $S$. violascens BF 3. 10 with porang glucomannan concentration of $0.25 \%, 0.50 \%$, and $1 \%$ in $10 \mathrm{~mL}$ enzyme solution, $30{ }^{\circ} \mathrm{C}$. Concentration of porang substrate of $0.25 \%$ (口), $0.5 \%$ (䨽), $1 \%($ (घ)

Table 2. Degree of polymerization (DP) analysis with variations of porang glucomannan concentration $(0.25 \%, 0.5 \%$, and $1 \%$ in $10 \mathrm{~mL}$ enzyme solution, at $30{ }^{\circ} \mathrm{C}$ and 150 rpm)

\begin{tabular}{lcccc}
\hline $\begin{array}{l}\text { Substrate } \\
\text { concentration }\end{array}$ & $\begin{array}{c}\text { Time } \\
(\mathrm{h})\end{array}$ & $\begin{array}{c}\text { Total sugar } \\
(\mathrm{mg} / \mathrm{ML})\end{array}$ & $\begin{array}{c}\text { Reducing } \\
\text { sugar } \\
(\mathrm{mg} / \mathrm{ML})\end{array}$ & $\mathrm{DP}$ \\
\hline \multirow{3}{*}{$0.25 \%$} & 3 & 2.513 & 1.253 & 2.00 \\
& 5 & 2.595 & 1.247 & 2.08 \\
& 24 & 2.504 & 1.207 & 2.07 \\
$0.50 \%$ & 3 & 5.774 & 2.470 & 2.34 \\
& 5 & 6.319 & 2.710 & 2.33 \\
& 24 & 4.874 & 2.640 & 1.85 \\
$1.00 \%$ & 3 & 13.077 & 4.375 & 2.99 \\
& 5 & 11.668 & 5.008 & 2.33 \\
& 24 & 11.714 & 5.708 & 2.05 \\
\hline
\end{tabular}

enzyme of Streptomyces violascens BF 3.10 might be restricted to only degrade substrate into mannobiose and might not be able to degrade further into their monomer forms (mannose). The same degree of polymerization was observed at hydrolysis of konjac's glucomannan with DP ranging from 1-4 and the main product spreaded at DP of 2 (Kurakake et al., 2006). Konjac flour hydrolyzed by mannanase of Bacillus sp. MSJ-5 produced mannooligosaccharides with DP 2-6 (Zhang et al., 2009).

\section{Analyzing Mannooligosaccharides by Using TLC and HPLC}

Based on thin layer cromatography (TLC) analysis, mannooligosaccharides produced by mannanase $S$. violascens BF 3.10 consisted of glucose, mannobiose, mannotriose, and mannotetraose with mannotriose as the main product (Figure 6). It indicates that mannanase belongs to endo-mannanase type. Endo-mananase can degrade mannan polysaccharide to mannotetraose, mannotriose, and mannobiose (Jiang et al., 2006). The 
results of the analysis of hydrolysis of $0.5 \%$ porang glucomannan with incubation time for 5 hours using HPLC showed five peaks (Figure 7). Mannose monomers were detected in the first peak with a retention time of 4.176 min. Mannooligosaccharides products detected were mannobiose (5.179 $\mathrm{min})$, mannotriose (5.991 $\mathrm{min})$, mannotetraose (6.738 $\mathrm{min})$, and mannohexose (10.648 $\mathrm{min})$.

Endo $\beta$-mannanase is an important enzyme in degrading polysaccharide due to its ability to catalyze random hydrolysis of $\beta$-D-1,4-mannopyranosyl linkage (Alonso-Sande et al., 2009). Hydrolysis on this linkage from a glucomannan backbone will produce oligosaccharides in the form of mannobiose and mannotriose (Addemark et al., 1998). The ability of $\beta$-mananase to degrade glucomannan backbone depends on several factors, including number and distribution of the substituents on the backbone and the ratio of glucose and mannose (Mc Cleary et al., 1986). Recent studies reported that mannanase from certain bacteria can hydrolyze mannan into certain oligosaccharides, such as mannooligosaccharide production from palm kernel by mannanase of Brevibacillus borstelensis (Utami et al., 2013), also from copra pulp by recombinant of $A$. niger (Cuong et al., 2013), and from locust bean gum by using immobilized Penicillium occitanis mannanase (Blibech et al., 2011). Hydrolysis of porang glucomannan by mannanase of $S$. violascens BF 3.10 in this study produced the same products compared to hydrolysis of konjac flour by endo- $\beta$-mannanase MAN5 (Zhang et al., 2009). More than $90 \%$ polysaccharides were hydrolyzed by endo- $\beta$-mannanase MAN5 into oligosaccharides with DP 2-6 (Zhang et al., 2009). Some fungal mannanase hydrolyze mannotetraose to mannotriose and mannobiose through transglycosylation reaction (Puchart et al., 2004). The presence of mannose (monosaccharide) in the hydrolyzed mixture is the product of $\beta$-Mannosidase. $\beta$ Mannosidase, an exo-type enzyme, cleaves $\beta$-1,4-linked mannosides, releasing mannose from the non-reducing end of mannans and mannooligosaccharides (Dhawan \& Kaur, 2007). The presence of glucose product on the re-

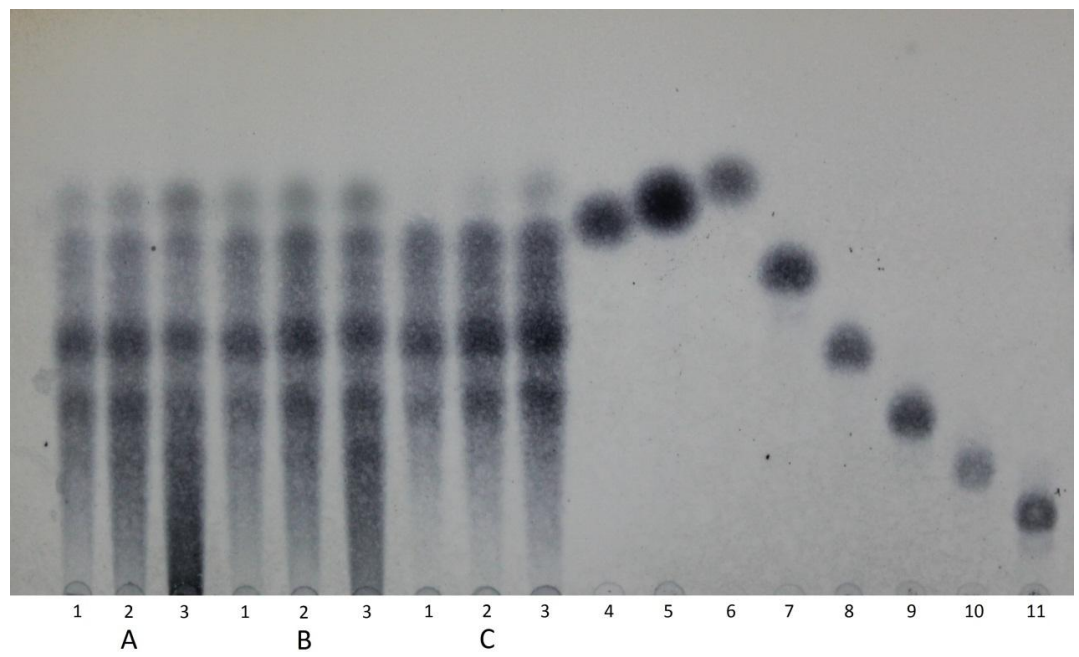

Figure 6. Thin layer chromatography analysis of the porang flour hydrolazed by Streptomyces violascens mannanase at the reaction time of $3 \mathrm{~h}(\mathrm{~A}), 5 \mathrm{~h}(\mathrm{~B})$, and $24 \mathrm{~h}(\mathrm{C}) .1=0.25 \%$ substrate concentration; $2=0.50 \%$ substrate concentration; $3=1.0 \%$ substrate concentration; $4=$ standard galactose; $5=$ standard glucose; $6=$ standard mannose; $7=$ standard mannobiose; $8=$ standard mannotriose; $9=$ standard mannotetraose; $10=$ standard mannopentose; $11=$ standard mannohexose.

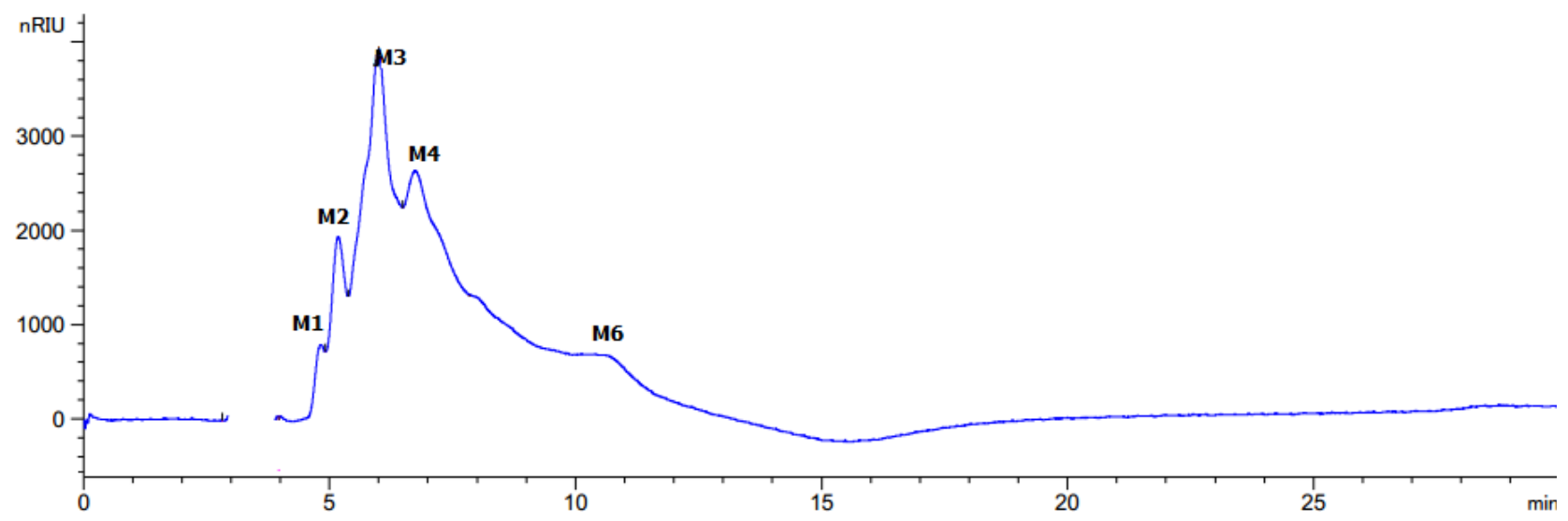

Figure 7. High performance liquid chromatography analysis of $0.5 \%$ porang glucomannan with incubation time for 5 hours hydrolyzed by mannanase Streptomyces violascens BF 3.10. M1= mannose; M2= mannobiose; M3= mannotriose; M4= mannotetraose; M6= mannohexose. 
sult of TLC analysis indicates that enzyme $\beta$-glucosidase cuts glucose terminal resulting in glucose side chain (Alonso-Sande et al., 2009).

Based on this study, porang could be an efficient substrate for mannanase production by $S$. violascens BF 31.0 to produce mannooligosaccharides. Manooligosaccharides are often used as ingredients in the formulation of functional feed, for example in cattle. Mannooligosaccharide produced by mannanase of $S$. violascens BF 3.10 is potentially developed as functional food or feed, acting as a prebiotic. Mannooligosaccharide should comply with many requirements to be classified as a prebiotic : resist gastric acidity, hydrolysis by mammalian enzymes and gastrointestinal absorption; fermented by the intestinal microflora; stimulates selectively the growth and/or activity of intestinal bacteria associated with health and wellbeing (Gibson \& Roberfroid, 2004). Endo- $\beta$-mannanase allows a large molecular weight glucomannan to be depolymerized into low molar weight fractions with lower DP (prebiotics belong to this group). Based on the chemical structure, the compounds of mannooligosaccharide are not absorbed in the upper part of the gastrointestinal tract or hydrolyzed by digestive enzymes, so it could potentially developed as prebiotic. Broiler chicks fed with prebiotics were increased in weight gain, feed conversation efficiency, nutrient digestibility, while the jejunal content viscosity was decreased (Sundu et al., 2006). On the other hand, dietary supplementation with prebiotics reduced some negative effects of heat stress in broilers (Sohail et al., 2010).

\section{CONCLUSION}

The corms of Porang (Amorphophallus muelleri Blume) was subjected to enzymatic hydrolysis by local isolate BF 3.10 (S. violascens BF 3.10) for the production of high quality mannooligosaccharides to develop its functional application as prebiotics. Characterization of the hydrolysis product afforded many kinds of mannooligosaccharides with DP 2-3. The result of this study suggested the potential of porang to be applied as prebiotics in the feed industry.

\section{ACKNOWLEDGEMENT}

Part of this research was funded by Start-up Program from CRC 990 for BO2 for Anja Meryandini.

\section{REFERENCES}

Ademark, P., A. Varga, J. Medve, V. Harjunpää, T. Drakenberg, F. Tjerneld, \& H. Stålbrand. 1998. Softwood hemicellulose-degrading enzymes from aspergillus niger: purification and properties of a $\beta$-mannanase. J. Biotechnol. 63: 199-210. http://dx.doi.org/10.1016/S0168-1656(98)00086-8

Adesina, F. C., O. A. Oluboyede, \& A. A. Onilude. 2013. Production, purification and characterisation of a $\beta$-mannanase by Aspergillus niger through solid state fermentation (SSF) of Gmelina arborea shavings. Afr. J. Microbiol. Res.7: 282-289.
Albrecht, S., G. C. van Muiswinkel, H. A. Schols, A. G. Voragen, \& H. Gruppen. 2009. Introducing capillary electrophoresis with laser-induced fluorescence detection (CE-LIF) for the characterization of konjac glucomannan oligosaccharides and their in vitro fermentation behavior. J. Agric. Food Chem. 57: 3867-3876. http://dx.doi.org/10.1021/jf8038956

Al-Ghazzewi, F. H., S. Khanna, R. F. Tester, \& J. Piggott. 2007. The potential use of hydrolysed konjac glucomannan as a prebiotic. J. Sci. Food. Agric. 87: 1758-1766. http://dx.doi. org/10.1002/jsfa.2919

Alonso-Sande, M., D. Teijeiro-Osorio, C. Remuñán-López, \& M. J. Alonso. 2009. Glucomannan, a promising polysaccharide for biopharmaceutical purposes. Eur. J. Pharm. Biopharm. 72:453-462. http://dx.doi.org/10.1016/ j.ejpb.2008.02.005

AOAC. 1995. Official Methods of Analysis. 16th ed. Assoc. Off. Anal. Chem., Arlington, Virginia, USA.

Bhoria, P., G. Singh, \& G. S. Hoondal. 2009. Optimization of mannanase production from streptomyces sp. pg-08-03 in submerged fermentation. BioResources.4: 1130-1138.

Blibech M., F. Chaari, F. Bhiri, I. Dammak, R. E. Ghorbel, \& S. E. Chaabouni. 2011. Production of manno-oligosaccharides from locust bean gum using immobilized Penicillium occitanis mannanase. J. Mol. Cataly. 73:111-115

Bommarius, A. S. \& J. M. Broering. 2005. Established and novel tools to investigate biocatalyst stability. Biocatal. Biotransform. 23: 125-139. http://dx.doi.org/10.1080/1024242050021 8877

Chua, M., T. C. Baldwin, T. J. Hocking \& K. Chan. 2010. Traditional uses and potential health benefits of Amorphophallus konjac K. Koch ex NE Br. J. Ethnopharm. 128: 268-278. http://dx.doi.org/10.1016/j.jep.2010.01.021

Cuong, D. B., V. K. Dung, N. T. T. Hien, \& D. T. Thu. 2013. Prebiotic evaluation of copra-derived mannooligosaccharides in white-leg shrimps. J. Aquac. Res. Development. 4:188. http://dx.doi.org/10.4172/2155-9546.1000188

Dhawan, S. \& J. Kaur. 2007. Microbial mannanase: an overview of production and applications. Crit. Rev. Biotechnol. 27:197-216. http://dx.doi.org/10.1080/07388550701775919

Dubois, K. A., Gilles, J. K. Hamilton, P. A. Rebers, \& F. Smith. 1956. Colorimetric method for determination of sugar and related substance. J. Anal. Chem. 28: 350-356. http://dx.doi. org/10.1021/ac60111a017

Fernandez F, M. Hinton, \& B. Van Gils. 2002. Dietary Mannan-oligosaccharides and Their Effect on chicken caecal microflora in relation to Salmonella Enteritidis colonization. Avian. Pathol. 31:49-58. http://dx.doi.org/10.1080/03079450 120106000

Gibson, G. R., H. M. Probert, J. Van Loo, R. A. Rastall, \& M. B. Roberfroid. 2004. Dietary modulation of the human colonic microbiota: updating the concept of prebiotics. Nutr. Res. Rev. 17: 259-275. http://dx.doi.org/10.1079/NRR200479

Illanes A. 2008. Enzime Biocatalysis. de Valpara' 1so: Springer Science, Business Media B.V. http://dx.doi.org/10.1007/9781-4020-8361-7

Jian, H. L., L. W. Zhu, W. M. Zhang, D. F. Sun, \& J. X. Jiang. 2013. Enzymatic production and characterization of mannooligosaccharides from Gleditsia sinensisgalactomannan gum. Int. J. Biol. Macromol. 55:282-288. http://dx.doi. org/10.1016/j.ijbiomac.2013.01.025

Jiang, Z., Y. Wei, D. Li, L. Li, P. Chai, \& I. Kusakebe. 2006. High level production, purification and characterization of thermostable $\beta$-mannanase from the newly isolated Bacillus subtilis WY34. Carbohydr. Pol. 66:88-96. http://dx.doi. org/10.1016/j.carbpol.2006.02.030

Kansoh, A. L. \& Z. A. Nagieb. 2004. Xylanase and mannanase enzymes from Streptomyces galbus NR and their use in biobleaching of softwood kraft pulp. Anton. Van. Leeuwonhoek. 85: 103-114. 
Khanongnuch, C., C. Sa-nguansook, \& S. Lumyong. 2006. Nutritive quality of mannanase treated copra meal in broiler diets and effectiveness on some fecal bacteria. Int. J. Poult. Sci. 5:1087-1091. http://dx.doi.org/10.3923/ ijps.2006.1087.1091

Kurakake, M., T. Sumid, D. Masuda, S. Oonishi, \& T. Komaki. 2006. Production of galacto-mannooligosaccharides from guar gum by $\beta$-mannanase from Penicillium oxalicum SO. J. Agric. Food. Chem. 54: 7885-7889. http://dx.doi. org/10.1021/jf061502k

Liao, T., L. Zhai, C. Gao, Y. Xue, \& Y. Ma. 2011. Purification and characterization of mannanase from an alkaliphilic mannanase producing bacterium HMTS15. Wei sheng wu xue bao. 51: 1520-1526.

Madigan M. T., J. M. Martinko, \& J. Parker. 2006. Brock Biology of Microorganisms. 10th ed. Prentice-Hall, Inc, New Jersey.

McCleary, B. V. \& N. K. Matheson. 1986. Polysaccharides based on a $(1 \rightarrow 4)-\beta$-D-mannan backbone. Adv. Carbohydr. Chem. Biochem. 44: 164-182.

Mendels, M. \& D. Sternberg. 1976. Microbial sources of cellulase. Appl. Microbial. 21:152-5.

Meryandini, A., R. Anggraeni, \& N. Rachmania. 2008. Isolation of mannanolitic bacteria and characterization of its mannanase. Biota. 13:82-88.

Miller G. L. 1959. Use of dinitrosalicylic acid reagent for determination of reducing sugar. Anal. Technol. 31:426-428. http://dx.doi.org/10.1021/ac60147a030

Pham, T. A., J. G. Berrin, E. Record, K.A. To, \& J. C. Sigoillot. 2010. Hydrolysis of softwood by Aspergillus mannanase; role of a carbohydrate-binding module. J. Biotechnol. 148:163-170. http://dx.doi.org/10.1016/j.jbiotec.2010.05.012

Poerba, S. Yuyu, \& M. Diyah. 2008. Genetic diversity based on random amplified polymorphic DNA (RAPD) markers in Amorphophallus muelleri Blume in Java. Technology. 9: 245249.

Puchart, V., M. Vrsanska, P. Svoboda, J. Pohl, Z. B. Ogel, \& P. Biely. 2004. Purification and characterization of two forms of endo- $\beta-1,4$-mannanase from a thermotolerant fungus, Aspergillus fumigatus IMI 385708 (formerly Thermomyces lanuginosus IMI 158749). Biochim. Biophys. Acta. 1674:239250. http://dx.doi.org/10.1016/j.bbagen.2004.06.022
Roberfroid, M. 2007. Prebiotics: the concept revisited. J. Nutr. 137(3): 830S-837S.

Shendare, R. C., M. A. Gongle, A. B. Rajput, B. V. Wanjari, \& S. M. Mandlekar. 2008. Effect of supplementation of manno-oligosaccharide and b-glucans on maize based meal on commercial broilers. Vet. World. 1: 13-15.

Sumarwoto. 2004. Review: constituen of mannan of iles-iles (Amorphophallus muelleri Blume). Bioteknologi. 4:28-32.

Sundu, B., A. Kumar \& J. Dingle. 2006. Response of broiler chicks fed increasing levels of copra meal and enzymes. Int. J. Poult. Sci. 5:13-18. http://dx.doi.org/10.3923/ ijps.2006.13.18

Sohail, M. U., A. Ijaz, M. S. Yousaf, K. Ashraf, H. Zaneb, M. Aleem, \& H. Rehman. 2010. Alleviation of cyclic heat stress in broilers by dietary supplementation of mannan-oligosaccharide and Lactobacillus-based probiotic: Dynamics of cortisol, thyroid hormones, cholesterol, C-reactive protein, and humoral immunity. Poult. Sci. 89:1934-1938. http:// dx.doi.org/10.3382/ps.2010-00751

Tester, R. F. \& F. H. Al-Ghazzewi. 2013. Mannans and health, with a special focus on glucomannans. Food. Res. Int. 50: 384-391. http://dx.doi.org/10.1016/j.foodres.2012.10.037

Thomas, W. R. 1997. Konjac gum. In thickening and gelling agents for food2nd ed(pp. 169-179). Springer US. Imeson, A., Ed., Blackie Academic \& Professional, London. p. 169.

Utami, W., A. Meryandini, \& K. G. Wiryawan. 2013. Characterization of bacterial mannanase for hydrolyzing palm kernel cake to produce mannooligosaccharidesprebiotics. Med. Pet. 36:192-196. http://dx.doi.org/10.5398/medpet.2013.36.3.192

Yopi, A. Purnawan, A. Thontowi, H. Hermansyah, \& A. Wijanarko. 2006. Preparasi mannan dan mannanasekasar dari bungkil kelapa sawit. J. Teknol. 4: 312-319.

Zhang, M., X. L. Chen, Z. H. Zhang, C. Y. Sun, L. L. Chen, H. L. He, B. C. Zhou, \& Y. Z. Zhang. 2009. Purification and functional characterization of endo- $\beta$-mannanase MAN5 and its application in oligosaccharide production from konjac flour. Appl. Microbiol. Biotechnol. 83:865-873. http://dx.doi.org/10.1007/s00253-009-1920-0 